\title{
Üniversite Öğrencilerinin Sosyal Medya Bağımlılık Düzeylerinin Çeşitli Değişkenlere Göre İncelenmesi
}

\author{
Ercan Aktan (Dr. Öğr. Üyesi) \\ Aksaray Üniversitesi İletişim Fakültesi \\ ercan_aktan@hotmail.com
}

Başvuru Tarihi: 17.01.2018

Yayına Kabul Tarihi: 03.05.2018

Yayınlanma Tarihi: 30.07.2018

Öz

Sosyal medya kavramı, ortaya atıldığı günden beri akademisyenleri, kullanıcıları ve iş dünyasını meşgul eden önemli bir konudur. Sosyal medya adı verilen, yeni iletişim biçimlerini ortaya çıkaran, etkileşime dayalı, paylaşım temalı bu yeni ortam; kullanıcıların gözdesi olmakla birlikte kendine ayrılan mesainin çok yoğun olması sonucunu da beraberinde getirmektedir. Sosyal medyanın bu yoğun kullanımı, problemli kullanım sorununa yol açmış, bu durum da sosyal medya bağımlılığı kavramının ortaya çıkmasını desteklemiştir. Bu araştırmada üniversite öğrencilerinin sosyal medya bağımlılık düzeyleri ölçülmeye çalışılmıştır. Bu maksatla araştırma, Aksaray Üniversitesi'nde öğrenim gören öğrenciler üzerinde uygulanmıștır. Elde edilen sonuçlara göre, katılımcıların sosyal medya bağımlılık düzeyleri "az bağımlı" seviyesinde bulunmuştur. Ayrıca araștırmada katılımcıların öğrenim gördükleri program, günlük sosyal medya kullanım süreleri, sosyal medyayı ne kadar zamandır kullandıkları değişkenleri ile sosyal medya bağımlılık düzeyleri arasında anlamlı bir farklılık olduğu sonucu ortaya konulmuştur. Bununla birlikte sosyal medya bağımlılık ölçeğinin alt faktörleri arasında pozitif yönde, anlamlı ilişki bir saptanmıştır.

Anahtar Kelimeler: Kullanımlar ve Doyumlar, Bağımlılık, Sosyal Ă̆, Sosyal Medya, İnternet Bağımlılığı, Sosyal Medya Bağımlılığı. 
Research Article

\title{
Assessment of Social Media Addiction Levels of University Students by Numerous Variables
}

\author{
Ercan Aktan (Asst. Prof. Dr.) \\ Aksaray University Faculty of Communication \\ ercan_aktan@hotmail.com
}

Date Received: 17.01 .2018

Date Accepted: 03.05.2018

Date Published: 30.07.2018

\begin{abstract}
The concept of social media is an important issue that has kept academics, users and the business world busy since the day it was introduced. This new media, called social media, which reveals new forms of communication and is based on interaction, causes the time left for itself to be too much, as well as being in fashion for the users. This intensive use of social media has led to the problem of problematic use, which has promoted the emergence of the concept of social media addiction. In this research, the social media addiction levels of university students were tried to be measured. For this purpose, the research was carried out on the students who studied at Aksaray University. According to the results obtained, participants' social media addiction levels were found to be at a "low level of addiction." In addition, it has been concluded that there is a significant difference between the variables such as participants' education program, period of using social media per day and how long they use social media, and the levels of social media addiction. However, a significant positive correlation between the sub-factors of social media addiction scale has been found.
\end{abstract}

Keywords: Uses and Gratifications, Addiction, Social Network, Social Media, Internet Addiction, Social Media Addiction. 


\section{Giriş}

Bireylerin bir konu, bir olay, bir nesne ya da bir araca gereğinden fazla, günlükyaşamını etkileyecek boyutta, ilişki ve iletişimlerinde tesiri dokunacak biçim ve boyutta zaman ayırması, bağlılık sergilemesi bir tür bağımlılık olarak değerlendirilebilmektedir. Sosyal medya, yeni ve daha önce görülmemiş biçim, içerik ve iletişim alt yapısı sayesinde kullanıcıların günlük programlarının önemli bir kısmını kapsamaktadır. Bu bakımdan sosyal medya, yeni bir bağımlılık unsuru olarak değerlendirilebilir. Diğer bir ifade ile sosyal medyanın bireylere sunmuş olduğu hizmetler ve teknik alt yapı bireylerin problemli kullanımlarına yol açarak bağımlılığa sebep olabilmektedir.

$\mathrm{Bu}$ çalışma daha önce yapılan ve teknoloji bağımlılığı, internet bağımlılığı, oyun bağımlılığı, Facebook bağımlılığı gibi konuları ele alan çalışmalardan ziyade sosyal medyayı Facebook, Twitter, YouTube, Instagram, FourSquare, Snapchat, Vine, Google+, Flickr gibi sosyal ağ sitelerini de içine alacak biçimde genişleterek ele almıştır.

İnternet kullanımı araştırmalarında neredeyse bütün dünyada ve ülkemizde daha çok öğrenciler tercih edilmiştir. Bu bağlamda internet kullanımı adeta bir gençlik ve bilgi araştırmaları olgusu içerisinde ele alınmıştır (Ayhan ve Çavuş, 2014, 51). Bu kapsamda araştırma Aksaray Üniversitesi Aksaray Sosyal Bilimler Meslek Yüksekokulu'nda öğrenim gören üniversite öğrencileri üzerinde yüz yüze anket uygulaması ile gerçekleștirilmiştir. Elde edilen veriler, sosyal bilimler için elektronik istatistik programına işlenmiştir. Araştırmada frekans analizlerinin yanı sıra, değişkenler arasındaki farklılığı ortaya koyabilmek amacıyla T Testi, ANOVA testleri, değişkenlerin ilişki durumunu test etmek amacıyla korelasyon analizi gerçekleştirilmiştir.

\section{Sosyal Medya Bağımlılığı}

Sosyal medya bağımlılığı, sosyal medya kullanımının son derece yoğunlaştığı günümüzde çokça tartışılmaya başlanan bir konu olmuştur. Sosyal medya bağımlılığı kavramının daha doğru bir biçimde anlaşılması için kullanımlar ve doyumlar yaklaşımının hatırlanmasında yarar bulunmaktadır. Kendisi dışındaki diğer yaklaşımların aksine, bireyin daha aktif olduğunu dile getiren ve bu nedenle kitle iletişim araçlarını tercihlerinin belirlenmesinde, kişinin kendi isteklerinin daha başat rol oynadığı düşüncesine sahip olan kullanımlar ve doyumlar yaklașımı, kullanıcının sahip olduğu isteklerin medya tercihinde temel belirleyici olduğu fikri üzerinde durmaktadır.

Bireylerin yakın çevrelerinden dünyanın geri kalanına kadar geniş bir alanda olup bitenlerden haberdar olması ile ürün ve hizmetlere ilişkin bilgi edinmesi, boş zamanlarını değerlendirerek eğlenmesi gibi işlevleri kitle iletişim araçları sağlamaktadır. Bu sebeple kitle iletişim araçları günlük yaşam pratiklerinde önemli bir işleve sahiptir. Bireyler kitle iletişim araçlarını kullanarak birtakım gereksinimlerini karşılamakta ve medyadan elde ettiği doyumlarla psikolojik olarak rahatlamakta ve gerginlikleri azaltmaktadır. Fizyolojik gereksinimlerin dışında, psikolojik ve kültürel gereksinimlerin karşılanması noktasında da kitle iletişim araçları ortaya çıkmaktadır (Bayram, 2008, 322). Kullanımlar ve doyumlar yaklaşımı, bir doyumun söz konusu olduğunu, buna dayalı olarak da bir kullanımdan bahsedilebileceğini, medya izleyici ilişkisinin de ancak bu yönüyle anlașllabileceğini ifade etmektedir. Buna göre yaklaşım, insanların ihtiyaçlarının farkında oldukları, bunları açıklayabildikleri ve en iyi doyumu sağlayacak yolu özgürce seçebildikleri üzerinde durmaktadır (Küçükkurt 
ve diğerleri, 2009, 38). Yukarıda da vurgulandığı gibi, kullanımlar ve doyumlar yaklaşımı, izleyicilerin kendi gereksinimlerine göre iletişim araçlarını ve içeriklerini seçtiklerini ve kendi etkilerini kendileri aradığı görüşünü ve dolayısıyla "aktif izleyici" görüşünü getirmiştir (Balcı ve Ayhan, 2007, 177).

$\mathrm{Bu}$ yaklaşımın, özellikle sosyal medya ile kullanıcının zamandan, mekândan ve denetimden bağımsız bir șekilde içerik üretmesi, ürettiği içeriği dağıtması, yeniden üretmesi ve bu döngünün sürekli biçimde devam etmesine olanak tanıyan dijital çağda, daha çok ön plana çıktığı gözlenebilir. Ayrıca sosyal ağ siteleri gibi bazı araçların kullanıcıların ilgi alanlarına uygun biçimde sunduğu altyapı da onların kendi istek ve beklentilerine göre tercihler yapma konusunda özgür oldukları gerçeğini gündeme getirir. Bu sebeple sosyal medya çağının, bireylerin aktif biçimde ve kendi doyumları perspektifinden kitle iletişim tercihlerini değiştirdiği gözlenmektedir.

Dijital araçların kitle iletişim biçimi olarak kullanılması, yukarıda sayılan türden hazlar ve doyumlar ile özgürlük alanı oluşturmakla birlikte, kullanıcıların olumsuz kullanımları nedeniyle daha önceleri yaşanmayan bazı sorunların gündeme gelmesine sebep olmuş durumdadır. Dijital çağın en temel aktörleri arasında yer alan bilgisayar ve internet kullanımının olumlu ve olumsuz etkileri konusundaki tartışmalar son zamanlarda büyük ilgi görmektedir. Bilindiği gibi internet, çok çeşitli konuları mümkün kılan bir iletişim ortamı sunmaktadır. Bununla birlikte, internetin dikkate değer bir şekilde büyümesi tartışmalı bir konu ortaya çıkarmaktadır (Yang ve Tung, 2007, 80). Bu tartışma onlarca yıldır patolojik internet kullanımı, problemli internet kullanımı ve kompülsif internet kullanımı gibi farklı isimlerle de adlandırılan internet bağımlılığı kavramının gelişmesine yol açmıştır (Robertson ve diğerleri, 2018, 255). Young, internet bağımlılığının beş farklı türünden söz etmektedir. Bunlardan ilki bilgisayar oyunlarını içeren bilgisayar bağımlılığı, ikincisi internete odaklanan bağımlılık, üçüncüsü internette alışveriş ya da bahis, dördüncüsü çevrimiçi pornografi olarak sıralanırken, beșincisi ise sosyal paylaşım siteleri bağımlılığı olarak sıralanmaktadır. Sosyal medyanın önemli bir kısmını oluşturan sosyal ağ sitesi bağımlılığı en yeni bağımlılık türüdür (Kuss ve Griffiths, 2011, 3529).

$\mathrm{Bu}$ tartıșmalar neticesinde internet bağımlılığı, depresyon, bireyin kendini tanıma sorunları ve olumsuz duygular gibi günlük yaşamı kontrol etmek için yetersizlik olarak değerlendirilebilir (He ve diğerlerinden aktaran Fu ve diğerleri, 2017, 2). Aynı zamanda internet bağımlılı̆̆ı, herhangi bir birey için zararlı etkisi olabilen, internetin uygunsuz ve kalıcı kullanımı olarak da tanımlanmaktadır (Young, 1998).

Bu bağlamda sorunlu internet kullanımı şu kriterleri içerir (Young 1999'dan aktaran Yang ve Tung, 2007, 81):

1. İnternetle meşgul olmak,

2. Çevrimiçi olarak giderek daha uzun süreler geçirmek,

3. İnternet kullanımını azaltmak için tekrarlanan girişimler,

4. İnternet kullanımını azalttığınızda çekilme belirtilerinin gerçekleşmesi,

5. Zaman yönetimi problemleri,

6. Çevresel sıkıntı (aile, okul, iş, arkadaşlar),

7. Çevrimiçi harcanan zaman hakkında aldatma,

8. İnternet kullanımı yoluyla ruh modifikasyonu. 
İnternetin gelişimi ve teknolojik alt yapısının güçlenmesi ile kullanıcı katılımlı, çoğulcu bir yapıya sahip (Aktan ve Koçyiğit, 2016, 67) ve son zamanlarda oldukça popüler olan (Drahošová ve Balco, 2017) hayatımızda oldukça önemli rol oynayan sosyal medya, özellikle arkadaş çevresi ile kurulacak bağlantı ve yeni arkadaşlar ile ilişkileri geliştirmek için önemli bir sosyal platformdur. Bu yönüyle de sosyal medya yaşam ve günlük rutin üzerinde büyük bir etkiye sahiptir (Tulu, 2017, 1096). Bu bakımdan tabletler, cep telefonları ve iş yerinde her personelin kolayca internete ulaşabilmesi gibi sebepler, sosyal medya kullanımının toplumu endișelendiren bir boyuta gelmesinde önemli bir etken olmuștur (Şahin ve Yağcl, 2017, 525).

Sosyal medyanın en önemli bileșenlerinden olan sosyal ağ siteleri, kullanıcıların bireysel profiller oluşturabildiği, arkadaşlarıyla etkileşime girdiği ve ortak çlkarlara dayalı olarak diğer insanlarla buluşabileceği sanal topluluklardır (Kuss ve Griffiths, 2011, 3529) ve bu ağlarda özellikle gençlerin bir araya geldikleri gözlenmektedir (Casale ve Fioravanti, 2018, 312). Bu birliktelik esnasında bireylerin hoş vakit geçirmeleri sosyal ağlarda harcanan vaktin artmasına yol açmaktadır. Bu sürecin ileri boyutu ise sosyal medya bağımlılığı olarak tanımlanabilir.

Tıpkı madde bağımlılığı gibi, sosyal ağ siteleri bağımlılığı da ruh hali modifikasyonu (yani, duygusal durumların olumlu bir şekilde değiştirilmesinde sosyal ağ sitelerinin müdahalesi), belirginlik (davranışsal, bilişsel ve duygusal meşguliyet) "klasik" bağımlılık belirtileri deneyimini içermektedir (Kuss ve Griffiths, 2011, 3530).

$\mathrm{Bu}$ özellikleri taşımakla birlikte net bir tanımı olmayan sosyal medya bağımlılığı (Eijnden ve diğerleri, 2016, 478) internet bağımlılığının bir alt alanı olarak ifade edilir (Longstreet ve Brooks, 2017, 74). Ya da sosyal medyanın bağımlı kullanımı (Facebook, Snapchat, Twitter gibi) belirli bir teknoloji bağımlılığı biçimi olarak görülebilir (Turel ve diğerleri, 2018, 84). Yapılmış net bir tanımın olmaması ve sosyal medya bağımlılığına karşı herhangi bir önlemin alınmaması, konuyla ilgili araştırma alanındaki adımları da engellemektedir (Eijnden ve diğerleri, 2016, 478).

\section{2. İlgili Araştırma Bulguları}

Literatür incelendiğinde çalışmaların genelde internet bağımlılığı ve Facebook bağımlılığı üzerine yoğunlaştığı görülmektedir. A.B.D.'de, 251 üniversite öğrencisi üzerinde yapılan araștırmada sosyal medya bağımlılığı ile yaşam tatmini arasında ilişki ortaya konulmuş, sosyal medya bağımlılığının yaşam tatminini düşüren bir etkisi olduğu vurgulanmıştır (Longstreet ve Brooks, 2017).

Ho ve diğerleri (2017) tarafından Singapur'da bin yetişkin ve dört bin 920 genç ile gerçekleştirilen ve bu iki grup arasındaki bağımlığı öngören faktörleri ölçmeye çalışan araştırmada, gençlerin yetişkinlere göre daha çok bağımlılık davranışları sergiledikleri ve bireylerin öz kimlik algıları ile aşırı sosyal ağ kullanımı arasında güçlü bir ilişki olduğu sonucuna erişilmiştir.

Robertson ve diğerleri (2018) ise 18-61 yaş arası, İspanyol, Kafkas, Afro-American ve Asya kökenli 240 katılımcı üzerinde gerçekleștirdikleri araştırmada, genel olarak, katılımcıların esneklik seviyesinin yüksekliği ile internet bağımlılığı seviyeleri arasında negatif bir ilişki bulunmuş, aynı ilişkiye çevrimiçi oyun bağımlılığında da rastlanmış ancak Facebook bağımlılığında bunun tersi bir ilişki bulunduğu ortaya konulmuştur. 
Choi ve Lim (2016) ise "Effects of social and technology overload on psychological well-being in young South Korean adults: The mediatory role of social network service addiction (Güney Koreli Genç Yetişkinlerde Sosyal ve Teknolojik Așırı Yükün Psikolojik İyi Oluşa Etkileri: Sosyal A ̆̆ Hizmeti Bağımlılığının Arabulucu Rolü)" isimli çalışmalarında 419 üniversite öğrencisi ve çalışan bireylerden oluşan örneklem grubu üzerinde, sosyal medya ve bilgi teknolojilerinin aşırı yüklenmesinin psikolojik yönden sağlık üzerinde doğrudan etkili olmadığını ortaya koymuştur.

Elhai ve diğerleri (2018) bireylerde akıllı telefon ve sosyal medya yoksunluğunun depresyon, kaygı ve stres ile ilişkisini ölçtükleri çalışmada yaş ve cinsiyete göre sosyal medya yoksunluğu ile depresyon, kaygı ve stres arasında bir ilişki olduğunu ortaya koyarken; sosyal medya yoksunluğunun yine duygu bozukluğuna yol açtığını da tespit etmişlerdir.

Savcı ve Aysan (2017) tarafından 201 ergen üzerinde gerçekleştirilen araştırmada sosyal bağlılık ile internet bağımlılığı, sosyal medya bağımlılı̆̆ı, dijital oyun bağımlılığı ve akıllı telefon bağımlılığı arasındaki ilişki ölçülmüş ve sonuç olarak sosyal bağlılığın \% 25 oranında açıklandığı ortaya konulmuştur. Bununla birlikte sosyal bağlılığın açıklanmasında en güçlü etkinin internet bağımlılığından geldiği ve bunu sırasıyla sosyal medya bağımlılığı, dijital oyun bağımlılığı ve akıllı telefon bağımlılığının takip ettiği saptanmıştır.

Balcı ve Gölcü'nün (2013) 903 üniversite öğrencisi ile gerçekleștirdikleri araştırmada katılımcıların günlük Facebook kullanım süresi ve yalnızlık düzeyleri ile Facebook bağımlılık düzeyi arasında pozitif yönde anlamlı ilişkinin varlığı ortaya konulmuştur. Ayrıca çalışma sonucunda, katılımcıların Facebook kullanım amaçlarına göre Facebook bağımlılıklarının da farklılaștığı sonucu elde edilmiştir.

\section{Yöntem}

$\mathrm{Bu}$ araştırma üniversite öğrencilerinin sosyal medya kullanım durumları ve sosyal medya bağımlılıklarının çeşitli değişkenler açısından ele alınarak ortaya konulmasını amaçlamaktadır.

\subsection{Araştırmanın Amacı ve Önemi}

Teknoloji bağımlılığı, medya bağımlılığı, problemli internet kullanımı gibi çeşitli kavramlarla adlandırılan ve bireyler üzerinde negatif yönde etkileri bulunan bazı bağımlılık türleri, özellikle Web 2.0 döneminde sıkça tartışılan konular arasındaki yerlerini almış durumdadır. Konu hakkında çeşitli tartışmalar yapılmakta ve çözüm önerileri ortaya konulmaya çabalanmaktadır. Bu çalışma da durumun ortaya konulması ve olası birtakım önerilerle tartışmaya destek verilmesi düşüncesiyle ortaya çıkmıştır.

$\mathrm{Bu}$ açıdan araştırmada, üniversite öğrencilerinin sosyal medyaya dair, bağımlılık seviyesinde kullanımlarının olup olmadığı tespit edilmeye çalışılmaktadır. Dolayısıyla üniversite öğrencilerinin sosyal medyaya karşı nasıl bir bağımlılı seviyesine sahip olduklarını ortaya koymak, araştırmanın temel problemini oluşturmaktadır. Araştırma, var olan bağımlılık durumunu ortaya koymak ve böylece gerekli önlemlerin alınması için rehberlik edecek olması bakımından önemlidir.

\subsection{Araştırmanın Modeli}

$\mathrm{Bu}$ araştırma genel tarama modelinde gerçekleştirilmekle birlikte çalışmanın bağımlı ve bağımsız değișkenleri arasında karşılaştırmalı ilişkisel tarama yapılmıştır. 
Katılımcıların sosyo-demografik özellikleri ile sosyal medya bağımlılıkları arasında ilişki ve farklılıkları ortaya koymak amacıyla veriler toplanmıştır.

\subsection{Araştırmanın Örneklem Seçimi, Veri Toplama Aracı ve Kullanılan Testler}

Araştırma, örnekleme ulaşım kolaylığı sebebiyle Aksaray Üniversitesi Sosyal Bilimler Meslek Yüksekokulu Halkla İlişsiler ve Tanıtım, Büro Yönetimi ve Yönetici Asistanlı̆̆ı, Muhasebe ve Vergi Uygulamaları, Turizm ve Otel İşletmeciliği ile Özel Güvenlik ve Koruma Programlarında öğrenim gören 315 öğrenci üzerinde yüz yüze anket uygulaması ile gerçekleștirilmiş, 13 anket formu çeşitli nedenlerle analiz dışı bırakılmıș, bu nedenle 302 anket analize tabi tutulmuştur.

Araştırmada kullanılan ölçek, Ünal'ın (2015) “Sosyal Medya Bağımlılığı Üniversite Öğrencileri Üzerine Bir Araştırma” isimli çalışmasında kullandığı Sosyal Medya Bağımlılığı Ölçeği'nden faydalanılarak oluşturulmuştur. 41 soruluk Likert tipi yargılardan oluşan ölçek, "meşguliyet, duygu durum, tekrarlama ve çatışma" olmak üzere 4 alt faktörden oluşmaktadır. Meşguliyet faktörü 12, duygu durum faktörü 5, tekrarlama faktörü 5, çatışma faktörü ise 19 maddeden oluşmaktadır. Ölçekteki ifadeler "1=Hiçbir zaman, 2=Nadiren, 3=Bazen, 4=Sıksık, 5=Her zaman" biçiminde yöneltilmiştir.

Araștırmada kullanılan Sosyal Medya Bağımlılık Ölçeği'nin puanlandırılması şu şekildedir:

Tablo 1: Sosyal Medya Bağımlığı Ölçeği ve Alt Ölçekleri Puanlama Tablosu

\begin{tabular}{|c|c|c|}
\hline Alt Ölçek/Ölçek & Puan Aralığı & Bağımlılık Seviyesi \\
\hline \multirow{5}{*}{$\begin{array}{l}\text { Sosyal Medya } \\
\text { Bağımlılığı Ölçeği }\end{array}$} & $41-73$ & Bağımlılık Yok \\
\hline & $74-106$ & Az Bağımlı \\
\hline & $107-139$ & Orta Bağımlı \\
\hline & $140-172$ & Yüksek Bağımlı \\
\hline & $173-205$ & Çok Yüksek Bağımlı \\
\hline \multirow{5}{*}{ Meşguliyet Faktörü } & $12-21$ & Bağımlııı Yok \\
\hline & $22-31$ & Az Bağımlı \\
\hline & $32-41$ & Orta Bağımlı \\
\hline & $42-51$ & Yüksek Bağımlı \\
\hline & $52-60$ & Çok Yüksek Bağımlı \\
\hline \multirow{5}{*}{$\begin{array}{l}\text { Duygu Durum } \\
\text { Düzenleme Faktörü }\end{array}$} & $5-8$ & Bağımlııı Yok \\
\hline & $9-12$ & Az Bağımlı \\
\hline & 13-16 & Orta Bağımlı \\
\hline & $17-20$ & Yüksek Bağımlı \\
\hline & $21-25$ & Çok Yüksek Bağımlı \\
\hline \multirow{5}{*}{ Tekrarlama Faktörü } & $5-8$ & Bağımlıık Yok \\
\hline & $9-12$ & Az Bağımlı \\
\hline & $13-16$ & Orta Bağımlı \\
\hline & $17-20$ & Yüksek Bağımlı \\
\hline & $21-25$ & Çok Yüksek Bağımlı \\
\hline \multirow{5}{*}{ Çatışma Faktörü } & $19-33$ & Bağımlııı Yok \\
\hline & $34-48$ & Az Bağımlı \\
\hline & $49-63$ & Orta Bağımlı \\
\hline & $64-78$ & Yüksek Bağımlı \\
\hline & $79-95$ & Çok Yüksek Bağımlı \\
\hline
\end{tabular}


Araştırmada katılımcıların yargılara ne ölçüde katıldıklarını tespit etmek amacıyla frekans analizleri gerçekleștirilmiş, faktörler arası ilișkiyi tespit etmek amacıyla korelasyon analizleri yapılmıș, değișkenler arasındaki farkları ortaya koyabilmek amacıyla ANOVA ve T Testleri uygulanmıștır.

\subsection{Araştırma Soruları ve Hipotezler}

Bu araştırma üniversite öğrencilerinin sosyal medya bağımlılık düzeylerini ele almayı amaçlamaktadır. Katılımcıların sosyal medya bağımlılık düzeyleri çeşitli değişkenler açısından değerlendirilmiştir. Araştırmada aşağıdaki sorulara yanıt aranmıştır:

- Katılımcıların sosyal medya bağımlılık düzeyleri nedir?

H1: Araştırmaya katılanlar, yüksek düzeyde sosyal medya bağımlılığına sahiptir.

- Katılımcıların sosyal medya kullanım süreleri ile bağımlılık düzeyleri arasında nasıl bir ilişki vardır?

H2: Katılımcıların günlük sosyal kullanım süreleri arttıkça sosyal medya bağımlılık seviyeleri de artmaktadır.

H3: Sosyal medya kullanım yılı arttıkça sosyal medya bağımlılığı artmaktadır.

- Katılımcıların demografik özelliklerine göre sosyal medya

bağımlılık düzeyleri arasındaki farklılık var mıdır?

- Sosyal Medya ölçeği alt faktörleri arasında nasıl bir ilişki vardır?

H4: Sosyal medya bağımlılı̆̆ı alt faktörleri arasında pozitif yönde ve anlamlı bir ilişki vardır.

\subsection{Bulgular ve Yorum}

Araștırma 11-22 Aralık 2017 tarihleri arasında gerçekleștirilmiştir. Araştırmadan elde edilen veriler, sosyal bilimler için istatistik programına işlenerek uygun analiz teknikleri ile analiz edilmiştir. Araştırmada kullanılan Sosyal Medya Bağımlılığı Ölçeği (SMBÖ) geçerliliği Cronbach's $\alpha=.952$ 'dir. Ölçeğin meşguliyet alt faktörü .905, duygu durum alt faktörü .844, tekrarlama alt faktörü .875 ve çatışma alt faktörü ise .929 geçerlilik oranlarına sahiptir. Bu değerlere göre ölçek güvenilir, araştırma geçerli bir araştırmadır.

Araştırmaya katılanlardan 147 (\% 48.7) kişi erkek, 149 kişi (\% 49.3) kadındır. Bu yönüyle araştırmanın kadın ve erkek temsili konusunda yeterli olduğu ortaya çıkmaktadır. Katılımcıların \% 18.2'si Halkla İlişkiler ve Tanıtım, \% 8.9’u Turizm ve Otel İşletmeciliği, \% 32.8'i Büro Yönetimi ve Yönetici Asistanlığl, \% 24.2'si Muhasebe ve Vergi Uygulamaları, \% 15.9'u da Özel Güvenlik ve Koruma Bölümü öğrencisidir. Aynı zamanda katılımcıların \% 48.7'si birinci sınıf, \% 51.3'ü de ikinci sınıf öğrencisidir.

Katılımcıların günlük internet kullanma sürelerinin \% 4'ü bir saatten az, \% 21.2 bir-iki saat arası, \% 32.5 üç-dört saat arası, \% 42.1 beş saat ve üzeri şeklinde olduğu sonucuna ulaşılmıştır. Ayrıca katılımcıların günlük \% 8 bir saatten az, \% 27.2 biriki saat arası, \% 32.5 üç-dört saat arası, \% 32.1 beş saat ve üzeri sosyal medya kullanım sürelerine sahip oldukları görülmektedir. Bununla birlikte katılımcıların \% 6.6'sı bir yıldan az, \% 13.2'si bir-iki yıldır, \% 32.1'i üç-dört yıldır, \% 47.4'ü de beş yıl ve üzeri sosyal medya kullanım süresine sahip olduklarını ifade etmiștir. Aynı zamanda katılımcıların \% 2.3'ünün masaüstü bilgisayar, \% 10.3'ünün dizüstü bilgisayar, \% 81.5'inin akıllı telefon, \% 5'inin tablet ile sosyal medyaya bağlandıkları sonucuna erişilmiştir. 
Tablo 2: Katılımcıların Sosyal Medya Bağımlılık Eğilimleri

\begin{tabular}{|c|c|c|c|}
\hline \multicolumn{2}{|c|}{ SOSYAL MEDYA BAĞIMLILIK ÖLÇEĞI } & \multirow{2}{*}{$\bar{x}$} & \multirow{2}{*}{ SD } \\
\hline \multicolumn{2}{|r|}{ 1= Hiçbir Zaman, 2=Nadiren, 3=Bazen, 4=Sık Sık, 5=Her Zaman } & & \\
\hline \multicolumn{4}{|c|}{ Meşguliyet Faktörü } \\
\hline 1 & $\begin{array}{l}\text { Yakın zamanda sosyal medyada neler olup bittiği } \\
\text { hakkında oldukça fazla düşünürüm. }\end{array}$ & 2.93 & 1.15 \\
\hline 2 & Yapmam gereken bir iş varsa öncesinde sosyal medyayı kontrol ederim. & 2.75 & 1.31 \\
\hline 3 & $\begin{array}{l}\text { Belli süre sosyal medyaya girmediğimde sosyal medyaya } \\
\text { girme düşüncesi zihnimi meşgul eder. }\end{array}$ & 2.92 & 1.32 \\
\hline 4 & Hayatımın sosyal medya olmadan sıkıcı, boş ve zevksiz olacağını düşünürüm. & 2.63 & 1.42 \\
\hline 5 & İnternete bağlı değilken yoğun bir şekilde sosyal medyaya girmeyi düşünürüm. & 2.74 & 1.28 \\
\hline 6 & Sosyal medyada neler olup bittiğini merak ederim. & 3.28 & 1.25 \\
\hline 7 & Sosyal medyada düşündüğümden daha fazla zaman geçirdiğim olur. & 3.14 & 1.27 \\
\hline 8 & $\begin{array}{l}\text { Sosyal medya ile bağlantımı kesmeye her karar verdiğimde } \\
\text { kendi kendime "birkaç dakika daha" derim. }\end{array}$ & 2.60 & 1.36 \\
\hline 9 & Sosyal medyayı uzun süre kullanmaktan bir türlü vazgeçemem. & 2.73 & 1.32 \\
\hline 10 & Sosyal medyayı, planladığımdan daha fazla kullandığım olur. & 3.06 & 1.29 \\
\hline 11 & Sosyal medyayı kullanırken zamanın nasıl geçtiğini anlayamam. & 3.36 & 1.32 \\
\hline 12 & $\begin{array}{l}\text { Sosyal medya ile ilgili eylemlere (oyun, sohbet, } \\
\text { fotoğraflara bakmak, vs) uzun süreler ayırırım. }\end{array}$ & 3.21 & 1.27 \\
\hline \multicolumn{4}{|c|}{ Duygu Durum Faktörü } \\
\hline 13 & Kişisel problemlerimi unutmak için sosyal medya kullanırım. & 2.80 & 1.37 \\
\hline 14 & Kendimi yalnız hissettiğim zamanlarda sosyal medyada vakit geçiririm. & 3.20 & 1.38 \\
\hline 15 & $\begin{array}{l}\text { Yaşamımdaki olumsuz düşüncelerden kurtulmak için } \\
\text { sosyal medyada gezinmeyi tercih ederim. }\end{array}$ & 2.73 & 1.34 \\
\hline 16 & Problemlerimden bunaldığımda sığındığım en iyi yer sosyal medyadır. & 2.40 & 1.32 \\
\hline 17 & Sosyal medya kullandığım süre boyunca her şeyi unuturum. & 2.11 & 1.23 \\
\hline \multicolumn{4}{|c|}{ Tekrarlama Faktörü } \\
\hline 18 & Sosyal medya kullanımını durdurmaya çalışıp başaramadığım olur. & 2.26 & 1.24 \\
\hline 19 & Sosyal medya kullanımını denetim altına almak için yoğun bir istek duyarım. & 2.26 & 1.24 \\
\hline 20 & Sosyal medya kullanımını bırakmak için sonuç vermeyen çabalar gösteririm. & 2.15 & 1.29 \\
\hline 21 & $\begin{array}{l}\text { Sosyal medya kullanımını denetim altına almak için } \\
\text { sonuç vermeyen çabalar gösteririm. }\end{array}$ & 2.08 & 1.18 \\
\hline 22 & Sosyal medyada harcadığım zamanı azaltmaya çalışır, başarısız olurum. & 2.28 & 1.29 \\
\hline \multicolumn{4}{|c|}{ Çatışma Faktörü } \\
\hline 23 & $\begin{array}{l}\text { Çalışmalarıma olumsuz bir etki yapmasına rağmen } \\
\text { sosyal medyayı daha fazla kullanırım. }\end{array}$ & 2.37 & 1.33 \\
\hline 24 & $\begin{array}{l}\text { Sosyal medyadan dolayı hobilerime, boş zaman ve } \\
\text { dinlenme faaliyetlerime daha az öncelik veririm. }\end{array}$ & 2.17 & 1.22 \\
\hline 25 & Aile üyelerini sosyal medyadan dolayı inmal ettiğim olur. & 2.12 & 1.21 \\
\hline 26 & Arkadaşlarımı sosyal medyadan dolayı inmal ettiğim olur. & 1.97 & 1.13 \\
\hline 27 & Sosyal medya dolayısıyla başladığım aktiviteleri zamanında bitiremem. & 1.98 & 1.17 \\
\hline 28 & $\begin{array}{l}\text { Sosyal medyada daha fazla zaman geçirmek için } \\
\text { okulla veya işle ilgili çalışmaları inmal ederim. }\end{array}$ & 1.81 & 1.10 \\
\hline 29 & $\begin{array}{l}\text { Sosyal medyada zaman geçirmeyi, arkadaşlarımla } \\
\text { zaman geçirmeye tercih ederim. }\end{array}$ & 1.96 & 1.26 \\
\hline 30 & $\begin{array}{l}\text { Sosyal medyada geçirdiğim zaman yüzünden okul } \\
\text { çalışmalarım ya da işlerim sekteye uğrar. }\end{array}$ & 1.93 & 1.18 \\
\hline 31 & Sosyal medya yüzünden üretkenliğim azalır. & 2.02 & 1.26 \\
\hline 32 & $\begin{array}{l}\text { Sosyal medyada zaman geçirmeyi, arkadaşlarımla } \\
\text { dışarı çıkmaya tercih ederim. }\end{array}$ & 2.10 & 1.37 \\
\hline
\end{tabular}




\begin{tabular}{|l|l|c|c|}
\hline $\mathbf{3 3}$ & $\begin{array}{l}\text { Insanlar sosyal medyada geçirdiğim zamanın } \\
\text { miktarı konusunda beni eleştirirler. }\end{array}$ & 2.04 & 1.21 \\
\hline $\mathbf{3 4}$ & $\begin{array}{l}\text { Kendimi sosyal medyada ne kadar süre gezindiğimi } \\
\text { saklamaya çalışırken bulurum. }\end{array}$ & 1.79 & 1.03 \\
\hline $\mathbf{3 5}$ & Sosyal medya yüzünden yemek yemeyi unuttuğum zamanlar olur. & 1.61 & 1.05 \\
\hline $\mathbf{3 6}$ & $\begin{array}{l}\text { Sosyal medya kullanımı yüzünden kişisel } \\
\text { bakımıma daha az vakit ayırdığım olur. }\end{array}$ & 1.79 & 1.15 \\
\hline $\mathbf{3 7}$ & $\begin{array}{l}\text { Sosyal medya kullanımı yüzünden uyku düzenimde } \\
\text { değişiklikler/bozukluklar olur. }\end{array}$ & 2.28 & 1.36 \\
\hline $\mathbf{3 8}$ & $\begin{array}{l}\text { Sosyal medya kullanımı yüzünden fiziksel sorunlar } \\
\text { (sırt, baş, göz ağrıları, vb) yaşadığım olur. }\end{array}$ & 2.21 & 1.24 \\
\hline $\mathbf{3 9}$ & $\begin{array}{l}\text { Sosyal medya kullanımı benim için önemli kişilerle olan } \\
\text { ilişkilerimde problem yaşamama neden olur. }\end{array}$ & 1.89 & 1.10 \\
\hline $\mathbf{4 0}$ & Sosyal medya kullanımım yaşamımda sorunlar oluşturur. & 1.93 & 1.13 \\
\hline $\mathbf{4 1}$ & $\begin{array}{l}\text { Yapmam gereken işler çoğaldıkça, sosyal medya } \\
\text { kullanma isteğim de o ölçüde artar. }\end{array}$ & 2.04 & 1.22 \\
\hline
\end{tabular}

Katılımcıların sosyal medya kullanım ölçeğindeki yargılara verdikleri yanıtlar incelendiğinde "Sosyal medyayı kullanırken zamanın nasıl geçtiğini anlayamam" $(\bar{X}=3.36)$, "Sosyal medyayı planladığımdan daha fazla kullandığım olur." $(\bar{X}=$ 3.06), "Sosyal medyada neler olup bittiğini merak ederim" ( $\bar{X}=3.28)$, "Sosyal medya ile ilgili eylemlere (oyun, sohbet, fotoğraflara bakmak vb.) uzun süreler ayırırım." $(\bar{X}=3.21)$, "Kendimi yalnız hissettiğimde sosyal medyada zaman geçirdiğim olur." $(\bar{X}=3.20)$ yargılarına daha fazla katıldıkları sonucuna erişilmiştir. Buna karşın katılımcıların "Sosyal medya yüzünden yemek yemeyi unuttuğum zaman olur." $(\bar{X}=1.61)$, "Sosyal medyada daha fazla zaman geçirmek için okulla veya işle ilgili çalışmaları ihmal ederim" ( $\bar{X}=1.81)$, "Sosyal medya dolayısıyla başladığım aktiviteleri zamanında bitiremem" ( $\bar{X}=1.98)$ yargılarına daha az katıldıkları anlaşılmaktadır (Tablo 2).

Tablo 3: Katılımcıların Sosyal Medya Bağımlılık Düzeyinin Dağılımı

\begin{tabular}{|l|c|c|}
\hline Ölçek/Alt Ölçek & $\overline{\mathbf{X}}$ & SD \\
\hline Sosyal Medya Bağımııı̆ı & 97.71 & 29.92 \\
\hline Meşguliyet Faktörü & 35.20 & 10.96 \\
\hline Duygu Durum Düzenleme Faktörü & 13.17 & 5.23 \\
\hline Tekrarlama Faktörü & 13.43 & 5.90 \\
\hline Çatışma Faktörü & 33.14 & 13.50 \\
\hline
\end{tabular}

Yukarıda yer alan Tablo 1'de yer alan puanlama tablosu çerçevesinde katılımcıların aldıkları toplam puanlara göre sosyal medya bağımlılıklarının ( $\bar{X}=97.71)$ "az bağımlı" (puan aralığı=74-106) düzeyinde olduğu anlaşılmaktadır. Elde edilen sonuçlar sonrası, katılımcıların yüksek sosyal medya bağımlılık seviyesine sahip olduklarını öngören $\mathbf{H 1}$ reddedilmiştir. Bununla birlikte katılımcıların bağımlılık düzeylerinin alt faktörler bakımından incelendiğinde; meşguliyet faktöründe $(\bar{X}=$ 35.20) "orta bağımlı" (puan aralığ $=32-41$ ), duygu durum düzenleme faktöründe $(\bar{X}=13.17)$ "orta bağımlı" (puan aralığ $l=13-16)$, tekrarlama faktöründe $(\bar{X}=13.43$ ) "orta bağımlı" (puan aralığı=13-16), çatışma faktöründe (X=33.14) "bağımlılık yok" (puan aralığı=19-33) düzeyinde olduğu görülmektedir (Tablo 3).

Elde edilen sonuçlara göre katılımcıların sosyal medya bağımlılık düzeylerinin az bağımlı seviyesinde olduğu söylenebilir. Bunun yanı sıra katılımcıların, sosyal medyadaki meşguliyet, duygu durum düzenleme, tekrarlama davranışları 
bakımından orta seviyede; buna karşın çatışma davranışları bakımından ise düşük düzeyde bağımlılığa sahip oldukları ortaya çıkmaktadır.

Tablo 4: Sosyal Medya Bağımlılık Düzeyinin Cinsiyete Göre Dağılımı

\begin{tabular}{|c|c|c|c|c|c|c|}
\hline Ölçek/Alt Ölçek & Cinsiyet & N & $\overline{\mathrm{X}}$ & sd & $\mathbf{t}$ & $\mathbf{p}$ \\
\hline \multirow{2}{*}{ Sosyal Medya Bağımlılığı } & Erkek & 117 & 98.05 & 30.27 & \multirow{2}{*}{.899} & \multirow{2}{*}{.370} \\
\hline & Kadın & 117 & 94.61 & 28.18 & & \\
\hline \multirow{2}{*}{ Meşguliyet Faktörü } & Erkek & 137 & 34.97 & 11.13 & \multirow{2}{*}{.-170} & \multirow{2}{*}{.865} \\
\hline & Kadın & 140 & 35.20 & 10.63 & & \\
\hline \multirow{2}{*}{$\begin{array}{l}\text { Duygu Durum } \\
\text { Düzenleme Faktörü }\end{array}$} & Erkek & 141 & 12.82 & 5.09 & \multirow{2}{*}{-955 } & \multirow{2}{*}{.340} \\
\hline & Kadın & 143 & 13.41 & 5.31 & & \\
\hline \multirow{2}{*}{ Tekrarlama Faktörü } & Erkek & 141 & 13.61 & 5.84 & \multirow{2}{*}{.729} & \multirow{2}{*}{.467} \\
\hline & Kadın & 138 & 13.10 & 5.80 & & \\
\hline \multirow{2}{*}{ Çatışma Faktörü } & Erkek & 134 & 34.16 & 13.84 & \multirow{2}{*}{1.52} & \multirow{2}{*}{.128} \\
\hline & Kadın & 129 & 31.68 & 12.44 & & \\
\hline
\end{tabular}

Araştırmada katılımcıların sosyal medya bağımlılık düzeyleri cinsiyete göre incelenmiştir. Uygulanan T Testi neticesinde sosyal medya bağımlılığı açısından kadın katılımcılar ile erkek katılımcılar arasında istatistiki açıdan anlamlı bir farklılık tespit edilememiştir ( $\mathrm{t}=.899$, $\mathrm{sd}=30.27, \mathrm{p}=370)$. Ölçek alt faktörleri bakımından konuya yaklaşıldığında yine katılımcıların cinsiyetleri bakımından bağımlılık düzeylerinde bir farklılığın olmadığı anlaşılmıştır (Tablo 4).

Tablo 5: Sosyal Medya Bağımlılık Düzeyinin Öğrenim Görülen Programa Göre Dağılımı

\begin{tabular}{|c|c|c|c|c|c|}
\hline \multirow{2}{*}{ Ölçek/Alt Ölçek } & \multirow{2}{*}{ Öğrenim Görülen Program } & \multicolumn{3}{|c|}{ Betimleyici İstatistikler } & \multirow{2}{*}{ Analiz } \\
\hline & & $\mathbf{N}$ & $\overline{\mathrm{X}}$ & SD & \\
\hline \multirow{5}{*}{$\begin{array}{l}\text { Sosyal Medya } \\
\text { Bağımlıık Ölçeği }\end{array}$} & Halkla İlişkiler ve Tanıtım & 46 & 103.17 & 29.39 & \multirow{5}{*}{$\begin{array}{c}\text { ANOVA } \\
\begin{array}{c}\mathrm{F}=1.99 \\
\mathrm{df}=4 \\
\mathrm{p}=.095\end{array}\end{array}$} \\
\hline & Turizm ve Otel İşletmeciliği & 25 & 95.52 & 26.84 & \\
\hline & Büro Yönetimi ve Yön. Asis. & 67 & 95.50 & 29.41 & \\
\hline & Muhasebe ve Vergi Uyg. & 63 & 100.12 & 30.39 & \\
\hline & Özel Güvenlik ve Koruma & 38 & 86.13 & 30.97 & \\
\hline \multirow{5}{*}{ Meşguliyet } & Halkla İlişkiler ve Tanıtım & 52 & 38.75 & 10.35 & \multirow{5}{*}{$\begin{array}{c}\text { ANOVA } \\
\begin{array}{c}\mathrm{F}=3.31 \\
\mathrm{df}=4 \\
\mathrm{p}=.011\end{array}\end{array}$} \\
\hline & Turizm ve Otel İşletmeciliği & 26 & 34.23 & 10.51 & \\
\hline & Büro Yönetimi ve Yön. Asis. & 90 & 35.56 & 11.43 & \\
\hline & Muhasebe ve Vergi Uyg. & 71 & 35.22 & 10.74 & \\
\hline & Özel Güvenlik ve Koruma & 44 & 30.79 & 10.12 & \\
\hline \multirow{5}{*}{ Duygu Durum Düzenleme } & Halkla İlişkiler ve Tanıtım & 54 & 13.94 & 5.29 & \multirow{5}{*}{$\begin{array}{c}\text { ANOVA } \\
\begin{array}{c}\mathrm{F}=1.75 \\
\mathrm{df}=4 \\
\mathrm{p}=.138\end{array}\end{array}$} \\
\hline & Turizm ve Otel İşletmeciliği & 27 & 12.40 & 4.47 & \\
\hline & Büro Yönetimi ve Yön. Asis. & 93 & 13.11 & 5.18 & \\
\hline & Muhasebe ve Vergi Uyg. & 70 & 13.94 & 5.31 & \\
\hline & Özel Güvenlik ve Koruma & 46 & 11.69 & 5.36 & \\
\hline \multirow{5}{*}{ Tekrarlama } & Halkla İlişkiler ve Tanıtım & 55 & 14.70 & 5.97 & \multirow{5}{*}{$\begin{array}{c}\text { ANOVA } \\
\begin{array}{c}F=1.15 \\
d f=4 \\
p=.330\end{array}\end{array}$} \\
\hline & Turizm ve Otel İşletmeciliği & 26 & 12.46 & 5.73 & \\
\hline & Büro Yönetimi ve Yön. Asis. & 85 & 13.23 & 5.88 & \\
\hline & Muhasebe ve Vergi Uyg. & 72 & 13.65 & 5.86 & \\
\hline & Özel Güvenlik ve Koruma & 47 & 12.51 & 5.95 & \\
\hline \multirow{5}{*}{ Çatışma } & Halkla İlişkiler ve Tanıtım & 49 & 32.71 & 12.72 & \multirow{5}{*}{$\begin{array}{c}\text { ANOVA } \\
\begin{array}{c}\mathrm{F}=2.03 \\
\mathrm{df}=4 \\
\mathrm{p}=.090\end{array}\end{array}$} \\
\hline & Turizm ve Otel İşletmeciliği & 27 & 33.03 & 13.01 & \\
\hline & Büro Yönetimi ve Yön. Asis. & 83 & 33.85 & 13.99 & \\
\hline & Muhasebe ve Vergi Uyg. & 66 & 35.72 & 13.97 & \\
\hline & Özel Güvenlik ve Koruma & 43 & 28.39 & 12.25 & \\
\hline
\end{tabular}


Katılımcıların öğrenim gördükleri program ile sosyal medyadaki meşguliyetleri arasında istatistiki açıdan anlamlı bir farklılık elde edilmiştir ( $\mathrm{F}=3.31, \mathrm{df}=4, \mathrm{p}=011)$. Yüzde 5 anlamlılık düzeyinde Tukey Testi verilerine göre meşguliyet alt faktöründeki anlamlı farklılık Halkla İlişkiler ve Tanıtım Programında öğrenim gören öğrenciler $(\bar{X}=38.75)$ ile Özel Güvenlik ve Koruma Programında öğrenim gören öğrenciler $(\bar{X}=30.79)$ arasında gözlenmektedir. Diğer bir ifade ile Halkla İlişkiler ve Tanıtım Programında öğrenim gören öğrenciler, Özel Güvenlik ve Koruma Programında öğrenim gören öğrencilere kıyasla sosyal medya ortamlarından daha fazla vakit geçirmekte, bu durum da onların bağımlılık seviyelerini artırmaktadır denilebilir. $\mathrm{Bu}$ sonuçlar üzerinde Halkla İlişkiler ve Tanıtım Programında öğrenim gören öğrencilerin aldıkları eğitim ve mesleki gereklilikler dolayısıyla sosyal medyaya harcanan zamanın fazla olması durumunun etkili olduğu söylenebilir. Bunun yanı sıra sosyal medya bağımlılık düzeyleri, duygu durum düzenleme, tekrarlama ve çatışma alt faktörü ile öğrenim görülen program arasında anlamlı bir farklılık tespit edilmemiştir (Tablo 5).

Tablo 6: Sosyal Medya Bağımlılık Düzeyinin Günlük Sosyal

Medya Kullanım Süresine Göre Dağılımı

\begin{tabular}{|c|c|c|c|c|c|}
\hline \multirow{2}{*}{ Ölçek/Alt Ölçek } & \multirow{2}{*}{ Sosyal Medya Kullanım Süresi } & \multicolumn{3}{|c|}{ Betimleyici İstatistikler } & \multirow{2}{*}{ Analiz } \\
\hline & & $\mathbf{N}$ & $\overline{\mathrm{X}}$ & SD & \\
\hline \multirow{4}{*}{$\begin{array}{l}\text { Sosyal Medya } \\
\text { Bağımlılık Ölçeği }\end{array}$} & 1 Saatten $A z$ & 20 & 73.60 & 23.33 & \multirow{4}{*}{$\begin{array}{c}\text { ANOVA } \\
\begin{array}{c}F=10.62 \\
d f=3 \\
p=.000\end{array}\end{array}$} \\
\hline & 1-2 Saat Arası & 66 & 89.15 & 26.64 & \\
\hline & 3-4 Saat Arası & 76 & 97.26 & 30.78 & \\
\hline & 5 Saat ve Üzeri & 77 & 108.64 & 28.11 & \\
\hline \multirow{4}{*}{ Meşguliyet } & 1 Saatten Az & 23 & 23.86 & 7.04 & \multirow{4}{*}{$\begin{array}{c}\text { ANOVA } \\
\begin{array}{c}F=31.14 \\
d f=3 \\
p=.000\end{array}\end{array}$} \\
\hline & 1-2 Saat Arası & 78 & 30.21 & 9.53 & \\
\hline & 3-4 Saat Arası & 91 & 36.09 & 10.09 & \\
\hline & 5 Saat ve Üzeri & 91 & 41.43 & 9.50 & \\
\hline \multirow{4}{*}{$\begin{array}{l}\text { Duygu Durum } \\
\text { Düzenleme }\end{array}$} & 1 Saatten Az & 25 & 9.96 & 4.33 & \multirow{4}{*}{$\begin{array}{c}\text { ANOVA } \\
\begin{array}{c}\mathrm{F}=10.80 \\
\mathrm{df}=3 \\
\mathrm{p}=.000\end{array}\end{array}$} \\
\hline & 1-2 Saat Arası & 79 & 11.65 & 4.59 & \\
\hline & 3-4 Saat Arası & 92 & 13.35 & 5.11 & \\
\hline & 5 Saat ve Üzeri & 94 & 15.13 & 5.31 & \\
\hline \multirow{4}{*}{ Tekrarlama } & 1 Saatten Az & 23 & 11.52 & 4.62 & \multirow{4}{*}{$\begin{array}{c}\text { ANOVA } \\
\begin{array}{c}\mathrm{F}=4.78 \\
\mathrm{df}=3 \\
\mathrm{p}=.003\end{array}\end{array}$} \\
\hline & 1-2 Saat Arası & 78 & 12.33 & 4.83 & \\
\hline & 3-4 Saat Arası & 93 & 13.08 & 5.78 & \\
\hline & 5 Saat ve Üzeri & 91 & 15.21 & 6.71 & \\
\hline \multirow{4}{*}{ Çatışma } & 1 Saatten Az & 23 & 28.60 & 12.37 & \multirow{4}{*}{$\begin{array}{c}\text { ANOVA } \\
\begin{array}{c}F=2.36 \\
d f=3 \\
p=.071\end{array}\end{array}$} \\
\hline & 1-2 Saat Arası & 71 & 31.43 & 12.78 & \\
\hline & 3-4 Saat Arası & 87 & 33.13 & 14.73 & \\
\hline & 5 Saat ve Üzeri & 87 & 35.75 & 12.72 & \\
\hline
\end{tabular}

Araştırmada katılımcıların günlük sosyal medya kullanım süreleri ile sosyal medya bağımlılık düzeyleri arasındaki var olan durum da incelenmiştir. Gerçekleștirilen ANOVA Testi ile katılımcıların günlük sosyal medya kullanım süreleri ve sosyal medya bağımlılık düzeyleri arasında anlamlı bir farklılık tespit edilmiştir ( $F=10.62$, $\mathrm{df}=3, \mathrm{p}=000$ ). Yüzde 5 anlamlılık düzeyi gözetilerek yapılan Tukey Testi sonuçlarına göre bu anlamlı farklılığın günlük 5 saat ve üzeri sosyal medya kullananlar ( $\bar{X}=$ 108.64) ile 1 saatten az $(\bar{X}=73.60)$ ve $1-2$ saat arası $(\bar{X}=89.15)$ kullananlardan kaynaklandığı görülmektedir. Bu sonuçlara göre günlük sosyal medya kullanım 
süresi arttıkça sosyal medya bağımlılık seviyesi de artmaktadır denilebilir. Böylece araştırmanın sosyal medya kullanım süresi ve sosyal medya bağımlılığı arasında ilişki öngören $\mathbf{H} 2$ kabul edilmiştir.

Aynı biçimde, katılımcıların meşguliyet alt faktörü bakımından günlük sosyal medya kullanım süreleri ile sosyal medya bağımlılıkları arasında anlamlı bir farklılık elde edilmiştir ( $\mathrm{F}=31.14, \mathrm{df}=3, \mathrm{p}=000)$. Tukey Testi sonuçlarına göre anlamlı farklılığın sosyal medyayı günlük 5 saat ve üzeri kullananlar ile $(\bar{X}=41.43) 1$ saatten az $(\bar{X}=23.86), 1-2$ saat arası ( $\bar{X}=30.21), 3-4$ saat arası $(\bar{X}=36.09)$ kullananlar arasinda olduğu anlaşılmaktadır. Benzer şekilde duygu durum düzenleme alt faktörü ile katılımcıların günlük sosyal medya kullanım süreleri arasında anlamlı bir ilişki ortaya çıkmaktadır $(\mathrm{F}=10.80, \mathrm{df}=3, \mathrm{p}=000)$. Bu farklılığın, Tukey Testi sonuçlarına göre, sosyal medyayı günlük 5 saat ve üzeri kullananlar $(\bar{X}=15.13)$ ile 1 saatten az $(\bar{X}=9.96)$ ve $1-2$ saat arası $(\bar{X}=11.65)$ kullananlardan kaynaklandığı görülmektedir.

Bununla birlikte, tekrarlama alt faktörü ile katılımclların günlük sosyal medya kullanım süreleri arasında da anlamlı bir ilişki ortaya çıkmıştır $(F=4.78, d f=3$, $\mathrm{p}=003)$. Anlamlı farklılığın ortaya çıktığı gruplar ise yine sosyal medyayı günlük 5 saat ve üzeri kullananlar $(\bar{X}=15.21)$ ile 1 saatten az $(\bar{X}=11.52)$ ve $1-2$ saat arası ( $\bar{X}=12.33)$ kullananlardan kaynaklandığı görülmektedir. Buna karşın çatışma alt faktörü açısından konuya bakıldığında gruplar arasında istatistiki açıdan anlamlı farklılık tespit edilememiştir $(\mathrm{F}=2.36, \mathrm{df}=3, \mathrm{p}=071)$. Diğer bir ifade ile katılımcıların günlük sosyal medya kullanım süreleri ile çatışma durumları arasında anlamlı bir ilişki söz konusu değildir (Tablo 6).

Tablo 7: Sosyal Medya Bağımlılık Düzeyinin Sosyal Medya Kullanım Yılına Göre Dağılımı

\begin{tabular}{|c|c|c|c|c|c|}
\hline \multirow{2}{*}{ Ölçek/Alt Ölçek } & \multirow{2}{*}{ Sosyal Medya Kullanım Yılı } & \multicolumn{3}{|c|}{ Betimleyici İstatistikler } & \multirow{2}{*}{ Analiz } \\
\hline & & $\mathbf{N}$ & $\overline{\mathrm{X}}$ & SD & \\
\hline \multirow{4}{*}{$\begin{array}{l}\text { Sosyal Medya } \\
\text { Bağımlılık Ölçeği }\end{array}$} & 1 Yıldan Az & 18 & 75.83 & 24.62 & \multirow{4}{*}{$\begin{array}{c}\text { ANOVA } \\
\begin{array}{c}F=4.09 \\
d f=3 \\
p=.007\end{array}\end{array}$} \\
\hline & 1-2 Yıldır & 26 & 90.11 & 28.14 & \\
\hline & 3-4 Yıldır & 77 & 99.15 & 25.88 & \\
\hline & 5 ve Üzeri Yıldır & 117 & 99.89 & 32.33 & \\
\hline \multirow{4}{*}{ Meşguliyet } & 1 Yıldan Az & 20 & 26.85 & 11.08 & \multirow{4}{*}{$\begin{array}{c}\text { ANOVA } \\
\begin{array}{c}F=5.84 \\
d f=3 \\
p=.001\end{array}\end{array}$} \\
\hline & 1-2 Yıldır & 36 & 33.75 & 10.95 & \\
\hline & 3-4 Yıldır & 91 & 34.83 & 9.73 & \\
\hline & 5 ve Üzeri Yıldır & 134 & 37.18 & 11.19 & \\
\hline \multirow{4}{*}{$\begin{array}{l}\text { Duygu Durum } \\
\text { Düzenleme }\end{array}$} & 1 Yıldan Az & 20 & 10.65 & 3.75 & \multirow{4}{*}{$\begin{array}{c}\text { ANOVA } \\
\begin{array}{c}\mathrm{F}=2.22 \\
\mathrm{df}=3 \\
\mathrm{p}=.085\end{array}\end{array}$} \\
\hline & 1-2 Yıldır & 38 & 13.28 & 5.41 & \\
\hline & 3-4 Yıldır & 93 & 12.90 & 4.72 & \\
\hline & 5 ve Üzeri Yıldır & 137 & 13.75 & 5.61 & \\
\hline \multirow{4}{*}{ Tekrarlama } & 1 Yıldan Az & 20 & 10.20 & 5.07 & \multirow{4}{*}{$\begin{array}{c}\text { ANOVA } \\
\begin{array}{c}\mathrm{F}=2.33 \\
\mathrm{df}=3 \\
\mathrm{p}=.074\end{array}\end{array}$} \\
\hline & 1-2 Yıldır & 36 & 13.44 & 5.78 & \\
\hline & 3-4 Yıldır & 92 & 13.97 & 5.52 & \\
\hline & 5 ve Üzeri Yıldır & 136 & 13.59 & 6.70 & \\
\hline \multirow{4}{*}{ Çatışma } & 1 Yıldan Az & 18 & 25.83 & 8.39 & \multirow{4}{*}{$\begin{array}{c}\text { ANOVA } \\
\begin{array}{c}F=2.33 \\
d f=3 \\
p=.063\end{array}\end{array}$} \\
\hline & 1-2 Yıldır & 29 & 30.75 & 13.81 & \\
\hline & 3-4 Yıldır & 86 & 33.80 & 12.69 & \\
\hline & 5 ve Üzeri Yıldır & 134 & 34.24 & 14.28 & \\
\hline
\end{tabular}


Araştırmada katılımcıların sosyal medyayı ne kadar süredir kullandıkları ile sosyal medya bağımlılıkları arasında bir bağıntının var olup olmadığını ortaya koyabilmek açısından da testler yapılmıştır (Tablo 7). Buna göre katılımcıların sosyal medyayı ne kadar süredir kullandıkları ile sosyal medya bağımlılık düzeyleri arasında anlamlı bir farklılık olduğu tespit edilmiştir ( $F=4.09, d f=3, p=003)$. Bu farklılığın ortaya çıktığı gruplar ise sosyal medyayı 5 ve üzeri yıldır kullananlar ( $\bar{X}=99.89)$ ile 1 yıldan az kullananlardır ( $\bar{X}=75.83)$. Diğer bir ifade ile sosyal medyayı 5 yıl ve üzerinde kullananlar, sosyal medyayı 1 yıldan az kullananlara göre daha fazla bağımlılığa sahiptir denilebilir. Bu sonuçlar ile katılımcıların sosyal medya kullanım yılı ve sosyal medya bağımlılıkları arasında ilişki öngören H3 kabul edilmiştir.

Bunun yanı sıra, alt faktörler açısından yapılan ANOVA Testi sonuçlarına göre sosyal medyayı kullanma yılı ve sosyal medya bağımlılığı arasında anlamlı farklılık yalnızca meşguliyet alt faktöründe tespit edilmiştir ( $\mathrm{F}=5.84, \mathrm{df}=3, \mathrm{p}=001) . \mathrm{Bu}$ anlaml farklılığın kaynaklandığı gruplar ise 5 ve üzeri yıldır sosyal medyayı kullananlar $(\bar{X}=37.18)$ ile 1 yıldan az kullananlardır ( $\bar{X}=26.85)$.

Tablo 8: Sosyal Medya Bağımlılı̆̆ı Alt Faktörlerinin Korelasyonu (Pearson r)

\begin{tabular}{|l|l|l|l|l|}
\hline $\begin{array}{l}\text { Faktörler Arası } \\
\text { Korelasyon Analizi }\end{array}$ & Meşguliyet & $\begin{array}{l}\text { Duygu Durum } \\
\text { Düzenleme }\end{array}$ & Tekrarlama & Çatışma \\
\hline Meşguliyet & 1 & & & \\
\hline Duygu Durum Düzenleme & $674^{\star \star}$ & 1 & & \\
\hline Tekrarlama & $587^{\star *}$ & $580^{\star *}$ & 1 & \\
\hline Çatışma & $496^{\star *}$ & $562^{\star *}$ & $634^{* \star}$ & 1 \\
\hline Not: ${ }^{* *} p<0.01$ &
\end{tabular}

Sosyal medya bağımlılığı faktörleri arasındaki ilişkinin düzeyini tanımlamak için yapılan korelasyon analizi incelendiğinde (Tablo 8); en güçlü ilişkinin meşguliyet faktörü ile duygu durum düzenleme faktörü arasında olduğu görülmektedir $(\mathrm{r}=.674, \mathrm{p}<0.01)$. Diğer bir ifade ile meşguliyet faktörü ile duygu durum faktörü arasında pozitif yönde, yüksek düzeyde ve anlamlı bir ilişki vardır. Bununla birlikte yine meşguliyet faktörü ile tekrarlama $(r=.587, p<0.01)$ ve çatışma $(r=.496$, $\mathrm{p}<0.01$ ) faktörleri arasında pozitif yönde, orta düzeyde ve anlamlı bir ilişki olduğu ortaya çıkmaktadır. Aynı zamanda duygu durum düzenleme faktörü ile tekrarlama $(\mathrm{r}=.580, \mathrm{p}<0.01)$ ve çatışma $(\mathrm{r}=.562, \mathrm{p}<0.01)$ faktörleri arasında da pozitif yönde, orta düzeyde ve anlamlı bir ilişki söz konusudur. Buna ilaveten tekrarlama faktörü ile çatışma faktörü $(r=.634, p<0.01)$ arasında pozitif yönde, yüksek düzeyde, anlamlı bir ilişki bulunmaktadır. Korelasyon analizi sonucu elde edilen bulgular sonucu H4 kabul edilmiştir.

\section{Sonuç}

Sosyal medya bağımlılığı, özellikle gelecek birkaç on yılda üzerinde önemle durulacak bir konu olarak görülmektedir. Bu hususta sosyal medyanın bağlayıcı ve bireylerin davranışlarını etkileyici, ciddi bir rolünün olması en önemli etken gibi görünmektedir. Özellikle Web 2.0 döneminin sunduğu teknik alt yapı sayesinde yeni iletişim ve yaşam biçimleri ortaya çıkaran sosyal medya; hızla gelişen, kendini yenileyen bir yapı ile birlikte Web 3.0, Web 4.0 dönemlerinin konuşulmaya başlanmasıyla yeni bağımlılık biçimlerinin tartışılmasına da zemin hazırlayacak boyutlara erişmektedir.

$\mathrm{Bu}$ araştırma, üniversite öğrencilerinin sosyal medya bağımlılık düzeyleri ve bu bağımlılık düzeylerinin çeşitli değişkenler çerçevesinde incelenmesi üzerine 
kurgulanmıştır. Araştırma neticesinde katılımcıların sosyal medya bağımlılık düzeylerinin, varsayımsal beklentinin aksine, "az bağımlı" seviyesinde çıktığı görülmektedir. $\mathrm{Bu}$ sonuç üzerinde katılımcıların üniversite öğrencileri olması sebebiyle belli bir bilinç seviyesine sahip olmalarının etkili olduğu düşünülebilir. Ancak elde edilen bu sonuç ile araştırma, Ho ve diğerleri (2017) tarafından Singapur'da gerçekleştirilen ve gençlerin sosyal ağlara bağımlılık seviyelerinin yüksek olduğunu ortaya koyan çalışmadan farklılaşmaktadır. Bu farklı sonuç, örneklem farklılığına bağlanabilir.

Katılımcıların sosyal medya bağımlılık seviyelerinin alt faktörler bakımından araştırılması neticesinde, sosyal medyadaki meşguliyet, duygu durum düzenleme, tekrarlama davranışları bakımından orta seviyede bağımlılık düzeylerine sahip oldukları; buna karşın çatışma alt faktörü bakımından ise düşük düzeyde bağımlılığa sahip oldukları sonucu elde edilmiştir. Elde edilen sonuçlara göre katılımcıların sosyal medya ortamlarında çatışma duygusunu çok fazla yaşamadıkları, bu sebeple sosyal medya kullanımları esnasında ve sonrasında çatışmadan kaynaklı olan huzursuzlukları yaşamayacak olmaları pozitif bir durum olarak değerlendirilebilir.

Elhai ve diğerleri (2018) tarafından gerçekleştirilen, akıllı telefon yoksunluğu ile depresyon, kaygı, stres ilişkisinin cinsiyete göre farklılaştığının tespit edildiği araştırmanın aksine; bu araştırmada katılımcıların sosyal medya bağımlılık düzeylerinin cinsiyet değişkenine göre bir farklılık oluşturmadığı, diğer bir ifade ile sosyal medya bağımlılığında kadın katılımcılar ve erkek katılımcılar arasında bir farklılığın olmadığı ortaya konulmuştur. Araştırmada, katılımcıların öğrenim gördükleri program ile meşguliyet alt faktörü arasında anlamlı bir fark olduğu, halkla ilişkiler ve tanıtım programı öğrencilerinin, özel güvenlik ve koruma programı öğrencilerine oranla sosyal medyada daha fazla meşguliyete sahip oldukları sonucuna varılmıştır. $\mathrm{Bu}$ sonuç üzerinde halkla ilişkiler ve tanıtım programı öğrencilerinin sosyal medyaya dair dersler alıyor olmaları ve bu mecralarda mesleki açıdan daha fazla mesaj üretmeleri beklenen öğrenciler olmalarının etkili olduğu söylenebilir. Aynı zamanda özel güvenlik ve koruma programı öğrencilerinin ise daha disiplinli ve koruma üzerine kurulu bir eğitim müfredatına sahip olmaları da sonuç üzerinde etkilidir.

Katılımcıların günlük olarak sosyal medyaya ayırdıkları vaktin artması, onların sosyal medya bağımlılığı üzerinde belirleyici unsurlardan biri olmaktadır. Buna göre araştırma bulguları, sosyal medyada günlük harcanan vaktin fazla olmasının sosyal medya bağımlılık düzeyini artırdığını da ortaya koymaktadır. Araștırma neticesinde bireylerin ne kadar zamandır sosyal medya ile birlikte oldukları, diğer bir ifade ile kaç yıldır sosyal medya kullandıkları ile sosyal medya bağımlılıkları arasında da anlamlı bir ilişki tespit edilmiştir. Başka bir deyişle bireylerin sosyal medya kullanım yılları arttıkça sosyal medya bağımlılık düzeylerinde de artışlar yaşandığı sonucuna ulaşılmıştır. Çalışma bu yönüyle Balcı ve Gölcü (2013) tarafından 903 üniversite öğrencisi üzerinde gerçekleştirilen Facebook kullanım süresi ile Facebook bağımlılık düzeyi arasında doğrusal bir ilişki ortaya koyan çalışma ile benzeşmektedir.

Elde edilen bu veriler de göstermektedir ki; bireylerin sosyal medyada geçirdikleri vaktin çoğalması bağımlılık düzeylerinin artmasına yol açmaktadır. Bu nedenle kullanıcıların sosyal medya bağımlısı olmamalarının ya da bağımlılık seviyelerinin düşük düzeyde olmasının sağlanabilmesi, kullanım sürelerinin kontrol altında 
tutulmasıyla gerçekleştirilebilir. Bu noktada, çocuk, genç ya da yetişkin kullanıcıların sosyal medya kullanım sürelerini denetim altında tutmaları bağımlılığın önüne geçilmesini sağlayan adımlardan biri olarak değerlendirilebilir.

Benzer şekilde araştırmada kullanılan sosyal medya bağımlılık ölçeğinin meşguliyet, duygu durum düzenleme, tekrarlama veçatışmaaltfaktörleriarasında da pozitifyönde ve anlamlı bir ilişki bulunmuştur. Diğer bir deyişle sosyal medyada gerçekleştirilen meşguliyet davranışı arttıkça, tekrarlama, çatışma ve duygu durum düzenleme yönündeki eylemlerde de artışlar yaşanacağı açıktır. Dolayısıyla kullanıcıların sosyal medya bağımlılığının alt faktörleri arasında yer alan bu türden durumların negatif etkilerinden uzak kalabilmelerinin yolunun, sosyal medyada geçirilen vaktin makul sürelerle sınırlandırılmasından geçtiği söylenebilir.

\section{Kaynakça}

Aktan, E. ve Koçyiğit, M. (2016). Sosyal Medya'nın Turizm Faaliyetlerindeki Rolü Üzerine Teorik Bir İnceleme. Dumlupınar Üniversitesi Sosyal Bilimler Dergisi(ICEBSS Özel Sayısı), 62-73.

Ayhan, B. ve Çavuş, S. (2014). İzleyici Araştırmalarında Değişim: Kullanımlar ve Doyumlardan Bağımlılığa. Selçuk İletişim, 8(2), 32-60.

Balcı, Ş. ve Ayhan, B. (2007). Üniversite Öğrencilerinin İnternet Kullanım ve Doyumları Üzerine Bir Saha Araştırması. Selçuk İletişim, 5(1), 174-197.

Balcı, Ş. ve Gölcü, A. (2013). Facebook Addiction among University Students in Turkey: "Selcuk University Example". Türkiyat Araștırmaları Dergisi(34), 255278.

Bayram, F. (2008). Gazete Okurlarının Okuma Motivasyonları ve Doyumları Üzerine Bir Kullanımlar ve Doyumlar Araştırması. Anadolu Üniversitesi Sosyal Bilimler Dergisi, 8(1), 321-336.

Casale, S. and Fioravanti, G. (2018). Why Narcissists are at Risk for Developing Facebook Addiction: The Need to be Admired and the need to belong. Addictive Behaviors (76), 312-318.

Choi, S. B. and Lim, M. (2016). Effects of social and technology overload on psychological well-being in young South Korean adults: The mediatory role of social network service addiction. Computers in Human Behavior(61), 245-254.

Drahošová, M. and Balco, P. (2017). The Analysis of Advantages and Disadvantages of Use of Social Media in European Union. Procedia Computer Science(109C), 1005-1009.

Eijnden, R. V., Lemmens, J. S., Valkenburg, P. M. (2016). The Social Media Disorder Scale. Computers in Human Behavior(61), 478-487.

Elhai, J. D., Hall, B., Erwin, M. (2018). Emotion regulation's relationships with depression, anxiety and stress due to imagined smartphone and social media loss. Psychiatry Research (261), 28-34.

Fu, J., Xu, P., Zhao, L., Yu, G. (2017). Impaired Orienting in Youth with Internet Addiction: Evidence from the Attention Network Task (ANT). Psychiatry Research, 1-16. 
Ho, S. S., Lwin, M., Lee, E. (2017). Till Logout do us Part? Comparison of Factors Predicting Excessive Social Network Sites Use and Addiction Between Singaporean Adolescents and Adults. Computers in Human Behavior(75), 632642.

Kuss, D. J. and Griffiths , M. (2011). Online Social Networking and Addiction-A Review of the Psychological Literature. International Journal of Environmental Research and Public Health(8), 3528-3552. doi:10.3390/ijerph8093528

Küçükkurt, M., Hazar, Ç., Çetin, M., Topbaş, H. (2009). Kullanımlar ve Doyumlar Yaklaşımı Perspektifinden Üniversite Öğrencilerinin Medyaya Bakışı. Selçuk İletişim, 6(1), 37-50.

Longstreet, P. and Brooks, S. (2017). Life satisfaction: A key to managing internet \& social media addiction. Technology in Society(50), 73-77.

Robertson, T. W., Yan, Z., Rapoza, K. (2018). Is resilience a protective factor of internet addiction? Computers in Human Behavior(78), 255-260. doi:10.1016/j. chb.2017.09.027

Savcı, M. ve Aysan, F. (2017). Teknolojik Bağımlılıklar ve Sosyal Bağlılık: İnternet Bağımlılığı, Sosyal Medya Bağımlılığı, Dijital Oyun Bağımlılığı ve Akıllı Telefon Bağımlılığının Sosyal Bağlılığı Yordayıcı Etkisi. Düşünen Adam(30), 202-216.

Şahin, C. ve Yağcı, M. (2017). Sosyal Medya Bağımlılı̆̆ı Ölçeği- Yetişkin Formu: Geçerlilik ve Güvenirlik Çalışması. Ahi Evran Üniversitesi Kırşehir Eğitim Fakültesi Dergisi (KEFAD), 18(1), 523-538.

Tulu, D. T. (2017). Should Online Social Medias (OSMs) be Banned at Work? The Impact of Social Medias on Employee Productivity in Ambo University, a Case study. Research in International Business and Finance (42), 1096-1102.

Turel, O., Brevers, D., Bechara, A. (2018). Time Distortion When Users at-Risk for Social Media Addiction Engage in Non-Social Media Tasks. Journal of Psychiatric Research(97), 84-88.

Ünal, A. T. (2015). Sosyal Medya Bağımlılı̆̆ı Üniversite Öğrencileri Üzerine Bir Araştırma. İstanbul: Marmara Üniversitesi Sosyal Bilimler Enstitüsü Gazetecilik Anabilim Dalı Yayımlanmamış Doktora Tezi .

Yang, S. C. and Tung, C.-J. (2007). Comparison of Internet addicts and non-addicts in Taiwanese high school . Computers in Human Behavior (73), 79-96.

Young, K. S. (1998). Internet Addiction: The Emergence of a New Clinical Disorder. CyberPsychology \& Behavior, 1(3), 237-244. 
